\title{
Modulation of transforming growth factor beta signalling pathway genes by transforming growth factor beta in human osteoarthritic chondrocytes: involvement of Sp1 in both early and late response cells to transforming growth factor beta
}

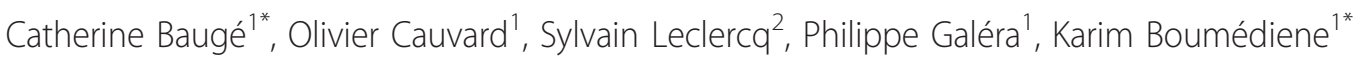

\begin{abstract}
Introduction: Transforming growth factor beta (TGF $\beta$ ) plays a central role in morphogenesis, growth, and cell differentiation. This cytokine is particularly important in cartilage where it regulates cell proliferation and extracellular matrix synthesis. While the action of TGF $\beta$ on chondrocyte metabolism has been extensively catalogued, the modulation of specific genes that function as mediators of TGF $\beta$ signalling is poorly defined. In the current study, elements of the Smad component of the TGF $\beta$ intracellular signalling system and TGF $\beta$ receptors were characterised in human chondrocytes upon TGF $\beta 1$ treatment.
\end{abstract}

Methods: Human articular chondrocytes were incubated with TGF $\beta 1$. Then, mRNA and protein levels of TGF $\beta$ receptors and Smads were analysed by RT-PCR and western blot analysis. The role of specific protein 1 (Sp1) was investigated by gain and loss of function (inhibitor, siRNA, expression vector).

Results: We showed that TGF $\beta 1$ regulates mRNA levels of its own receptors, and of Smad3 and Smad7. It modulates TGF $\beta$ receptors post-transcriptionally by affecting their mRNA stability, but does not change the Smad-3 and Smad-7 mRNA half-life span, suggesting a potential transcriptional effect on these genes. Moreover, the transcriptional factor Sp1, which is downregulated by TGF $\beta 1$, is involved in the repression of both TGF $\beta$ receptors but not in the modulation of Smad3 and Smad7. Interestingly, Sp1 ectopic expression permitted also to maintain a similar expression pattern to early response to TGF $\beta$ at 24 hours of treatment. It restored the induction of Sox 9 and COL2A1 and blocked the late response (repression of aggrecan, induction of COL1A1 and COL10A1).

Conclusions: These data help to better understand the negative feedback loop in the TGF $\beta$ signalling system, and enlighten an interesting role of Sp1 to regulate TGF $\beta$ response.

\section{Introduction}

Transforming growth factor beta (TGF $\beta$ ) controls a wide range of cellular responses, including differentiation, cell proliferation, migration, apoptosis, extracellular matrix remodelling and development. In cartilage, TGF $\beta$ plays a crucial role by functioning as a potent regulator

\footnotetext{
*Correspondence: catherine.bauge@unicaen.fr; karim.boumediene@unicaen. $\mathrm{fr}$ 'Université Caen, IFR ICORE 146, Laboratory of Extracellular Matrix and Pathology, Esplanade de la Paix, 14032 Caen cedex, France Full list of author information is available at the end of the article
}

of chondrocyte proliferation and differentiation, and of extracellular matrix deposition [1].

Biological effects of TGF $\beta$ are mediated by two different serine/threonine kinase receptors, named type I (TRRI) and type II (TRRII), which are both required for inducing signal transduction. Following binding of TGF $\beta$ to T $\beta$ RII, the ligand-bound type II receptor forms an oligomeric complex with the type I receptor, resulting in T $\beta R I$ phosphorylation. Activated T $\beta R I$ (also called ALK5) in turn transduces a number of secondary signals, most notably the activation of Smad2/3. T $\beta R I$ thus 
phosphorylates the receptor-regulated Smads (R-Smads) Smad2 and Smad3, which bind to Smad4, translocate into the nucleus and regulate gene expression in concert with other transcriptional factors, such as specific protein 1 (Sp1) [2,3]. Like R-Smads, the inhibitory Smad7 interacts with the activated type I TGF $\beta$ receptor. In contrast to $\mathrm{Smad} 2 / 3$, however, Smad7 forms a stable association with the receptor complex and prevents receptormediated phosphorylation of pathway-restricted Smads, resulting in disruption of TGF $\beta$ signalling [4].

In the cartilage context, it is thought that TGF $\beta$ signalling pathway plays a critical role for maintenance of tissue homeostasis, and modification of TGF $\beta$ signalling gene expression may be a cause for articular diseases such as osteoarthritis (OA) [5]. TßRII and Smad3, at least, are mediators of $\mathrm{OA}$, as established using in vitro and in vivo models. Indeed, Smad3 gene mutations in humans or targeted disruption in mice are associated with the pathogenesis of OA [6,7]. Similarly, mice that express a cytoplasmically truncated type II receptor, which acts as a dominant-negative mutant, develop a degenerative joint disease resembling human OA [8]. In addition, in vivo $\mathrm{OA}$ is associated with modifications of T $\beta$ RII and Smad7 expression $[9,10]$.

Several studies reported that TGF $\beta$ levels are increased, at least in the first stage of the disease [1,9]. We therefore wondered whether the modifications of expression of TGF $\beta$ signalling mediators observed during OA may be due, in part, to a feedback loop of TGF $\beta$.

Among numerous factors involved in the OA process and known to have the ability to regulate expression of TGF $\beta$ signalling genes, Sp1 seems to be particularly interesting. This protein is a trans-activator of cartilagespecific genes. The Sp1 knockdown is thus associated with reduction of collagen expression [11]. Sp1 is also involved in the regulation of Sox9 [12]. This transcriptional factor also cooperates with Smads to regulate expression of multiple TGF $\beta$ target genes $[2,3,13]$.

In the present report, we have investigated the effect of TGF $\beta 1$ treatment on expression of TGF $\beta$ signalling genes (receptors and Smads) and downstream genes (Sox9, COL2A1, aggrecan, COL10A1, COL1A1) in human articular chondrocytes. We demonstrate that whereas TGF $\beta$ treatment upregulates its receptors and Smad3 after short exposition time of TGF $\beta 1$ (< 1 hour), it causes a dramatic decrease of both TGF $\beta$ receptors, and of Smad3 expression after longer incubation. In marked contrast, the levels of antagonistic Smad7 were increased in TGF $\beta$-stimulated cells in all our experimental conditions. In addition, we showed that TGF $\beta 1$ induces a differential response according to the duration of treatment, with more beneficial effect for cartilage under short TGF $\beta$ exposition. We also established a role of $\mathrm{Sp} 1$ transcription factor in the downregulation of TGF $\beta$ receptors, and chondrocyte response to TGF $\beta$. Taken together, these results provide novel insights for the auto-modulation of TGF $\beta$ signalling in chondrocytes.

\section{Materials and methods Reagents}

Reagents were provided by Invitrogen (Bioblock Scientific, Illkirch, France) unless otherwise noted. TGF $\beta 1$ (R\&D Systems, Lille, France) was resuspended in PBS$\mathrm{HCl}$. Mithramycin and actinomycin D were obtained from Sigma-Aldrich Co. (St Quentin Fallavier, France). Oligonucleotides were supplied by Eurogentec (Angers, France).

\section{Cell culture}

OA human articular chondrocytes were prepared from femoral heads of patients who underwent hip replacement (ages between 63 and 81 years, median 77 years) as previously described [14]. All donors signed the agreement for this study according to the local ethical committee (Comité de protection des personnes). Cells were seeded at $4 \times 10^{4}$ cells $/ \mathrm{cm}^{2}$ and cultured in DMEM supplemented with $10 \%$ heat-inactivated FCS, $100 \mathrm{IU} / \mathrm{ml}$ penicillin, $100 \mu \mathrm{g} / \mathrm{ml}$ streptomycin and 0.25 $\mu \mathrm{g} / \mathrm{ml}$ fungizone, in a $5 \% \mathrm{CO}_{2}$ atmosphere. Cells were cultured for 5 to 6 days in 10\% FCS-containing DMEM. Then, at confluence, the cells were incubated in DMEM + 2\% FCS for 24 hours before adding TGF $\beta 1$ (1 to $10 \mathrm{ng} / \mathrm{ml}$ ) in the same medium.

\section{RNA extraction and real-time RT-PCR}

Total RNA from primary human articular chondrocyte cultures was extracted using Trizol. Following extraction, $1 \mu \mathrm{g}$ DNase-I treated RNA was reverse transcribed into cDNA as previously described [14]. Amplification of the generated cDNA was performed by real-time PCR in Applied Biosystems SDS7000 apparatus (Applied Biosystems Inc., Courtaboeuf, France). The relative mRNA level was calculated with the $2^{-\Delta \Delta C t}$ method. Primer sequences are presented in Table 1.

\section{Protein extraction and western blot analysis}

Cells were rinsed, and scrapped in RIPA lysis buffer supplemented with phosphatase and protease inhibitors. The extracts ( $50 \mu \mathrm{g}$ protein) were subjected to fractionation in 10\% SDS-PAGE, transferred to polyvinylidene fluoride membranes (Amersham Biosciences, Orsay, France), and reacted with T $\beta$ RI, T $\beta$ RII, Smad $2 / 3$ or phospho-Smad2/3 polyclonal antibodies (Tebu-bio, Le Perray en Yvelines, France). Subsequently, membranes were incubated with appropriate secondary peroxidaseconjugated antibody. The signals were revealed with 
Table 1 Primer sequences for the present study

\begin{tabular}{|c|c|c|}
\hline \multirow[t]{2}{*}{ Primer } & \multicolumn{2}{|c|}{ Sequence $\left(5^{\prime}\right.$ to $\left.3^{\prime}\right)$} \\
\hline & Sense & Antisense \\
\hline$T \beta R I$ & TTAAAAGGCGCAACCAAGAAC & GTGGTGATGAGCCCTTCGAT \\
\hline$T \beta R \|$ & GACATCAATCTGAAGCATGAGAACA & GGCGGTGATCAGCCAGTATT \\
\hline Smad2 & GCTGTITCCTAGCGTGGCTT & TCCAGACCCACCAGCTGACT \\
\hline Smad3 & GCATCAGCCGCTTCTCAAGT & ATCTCCCCACCATCACCTCC \\
\hline Smad4 & CCTTCTGGAGGAGATCGCT & TCAATGGCTTCTGTCCTGTGG \\
\hline Smad7 & AATGTGTTITCTAGATTCCCAACTTCTT & CACTCTCGTCTTCTCCTCCCAGTA \\
\hline Sp1 & AGAATTGAGTCACCCAATGAGAACA & GTTGTGTGGCTGTGAGGTCAAG \\
\hline COL2A1 & GGCAATAGCAGGTTCACGTACA & CGATAACAGTCTTGCCCCACTT \\
\hline COL1A1 & CACCAATCACCTGCGGTACAGAA & CAGATCACGTCATCGCACAAC \\
\hline COL10A1 & CCTGGTATGAATGGACAGAAAGG & CCCTGAGGGCCTGGAAGA \\
\hline Aggrecan & TCGAGGACAGCGAGGCC & TCGAGGGTGTAGCGTGTAGAGA \\
\hline Sox9 & CCC ATG TGG AAG GCA GAT G & TTC TGA GAG GCA CAG GTG ACA \\
\hline
\end{tabular}

SuperSignal West Pico Chemiluminescent Substrate (Pierce Perbio Science, Brébières, France) and exposed to $\mathrm{X}$-ray film. The membranes were also reacted with anti $\beta$-actin to verify equal loading.

\section{Transfection experiments}

Sp1 expression vector (pEVR2-Sp1) was obtained from Dr Suske (Institut fur Molekularbiologie and tumorforschung, Marburg, Germany). Chondrocytes were transiently transfected by the nucleofection method as previously described [14]. After overnight transfection, cells were treated with TGF $\beta 1$ (5 ng/ml) in DMEM containing $2 \%$ FCS. The silencing of Sp1 was performed using a siRNA targeting Sp1 (Tebu-Bio; Sp1 siRNA (h), sc-29487: AAUGAGAACAGCAACAACUCC) or a control sequence (UUGUCCGAACGUGUCACGUdtdt), as previously described [13].

\section{Statistical analysis}

All experiments were repeated with different donors at least three times with similar results, and representative experiments are shown in the figures. Data are presented as the mean \pm standard deviation. Statistical significance was determined by Student's $t$ test. Differences were considered statistically significant at $P<0.05$.

\section{Results}

TGF $\beta 1$ downregulates TGF $\beta$ receptors and Smad3, and upregulates Smad7

We investigated the effect of TGF $\beta 1$ on mRNA expression of TGF $\beta$ signalling genes in a dose-dependent manner, using real-time RT-PCR (Figure 1). A 48-hour incubation with TGF $\beta 1$ significantly reduced the expression of both TGF $\beta$ receptors and Smad3, whereas the Smad7 mRNA level was increased. These effects were maximal at $1 \mathrm{ng} / \mathrm{ml}$, except for T $\beta$ RII for which the maximal effect was observed only at doses above $5 \mathrm{ng} / \mathrm{ml}$. No significant effect was observed on Smad2 and Smad4.

TGF $\beta 1$ differentially regulates expression of its receptors and Smad3 according to duration of incubation

A time-course study (Figure $2 \mathrm{a}$ ) revealed that, at mRNA levels, TGF $\beta 1$ quickly upregulates its own receptors and Smad3, since it increases their expression as soon as 30 minutes of treatment. For longer treatments, TGF $\beta 1$ exerted the opposite effect and downregulated TGF $\beta$ receptors (after 24 hours of incubation) as well as Smad3 (after 3 hours of incubation). On the contrary, TGF $\beta 1$ upregulated Smad7 expression whatever the time of incubation.

Furthermore, western blot analysis (Figure 2b) showed that T $\beta$ RII is downregulated after 24 hours whereas $\mathrm{T} \beta \mathrm{RI}$ protein expression is decreased as soon as 1 hour after TGF $\beta 1$ treatment. In addition, as expected, TGF $\beta 1$ induced Smad2/3 phosphorylation - but this effect is transient since we were no longer able to detect phosphorylated Smad2/3 after 3 hours or 24 hours of treatment with TGF $\beta 1$.

TGF $\beta$ exerts differential effects on matrix genes and Sox9 according to duration of treatment

To evaluate the importance of the regulation of TGF $\beta$ pathways in cartilage homeostasis, we analysed mRNA expression of matrix genes (collagens type II, type I, and type $X$, and aggrecan) after increased duration of treatment (from 1 to 48 hours) (Figure 3). TGF $\beta 1$ acted with various kinetics according to the considered genes. It induced COL2A1 expression in a biphasic manner (at 3 hours and after 24 hours of treatment, with no stimulation for 6 hours of incubation). TGF $\beta 1$ repressed aggrecan expression after 6 hours of treatment, and upregulated COL1A1 as soon as 1 hour of incubation. 

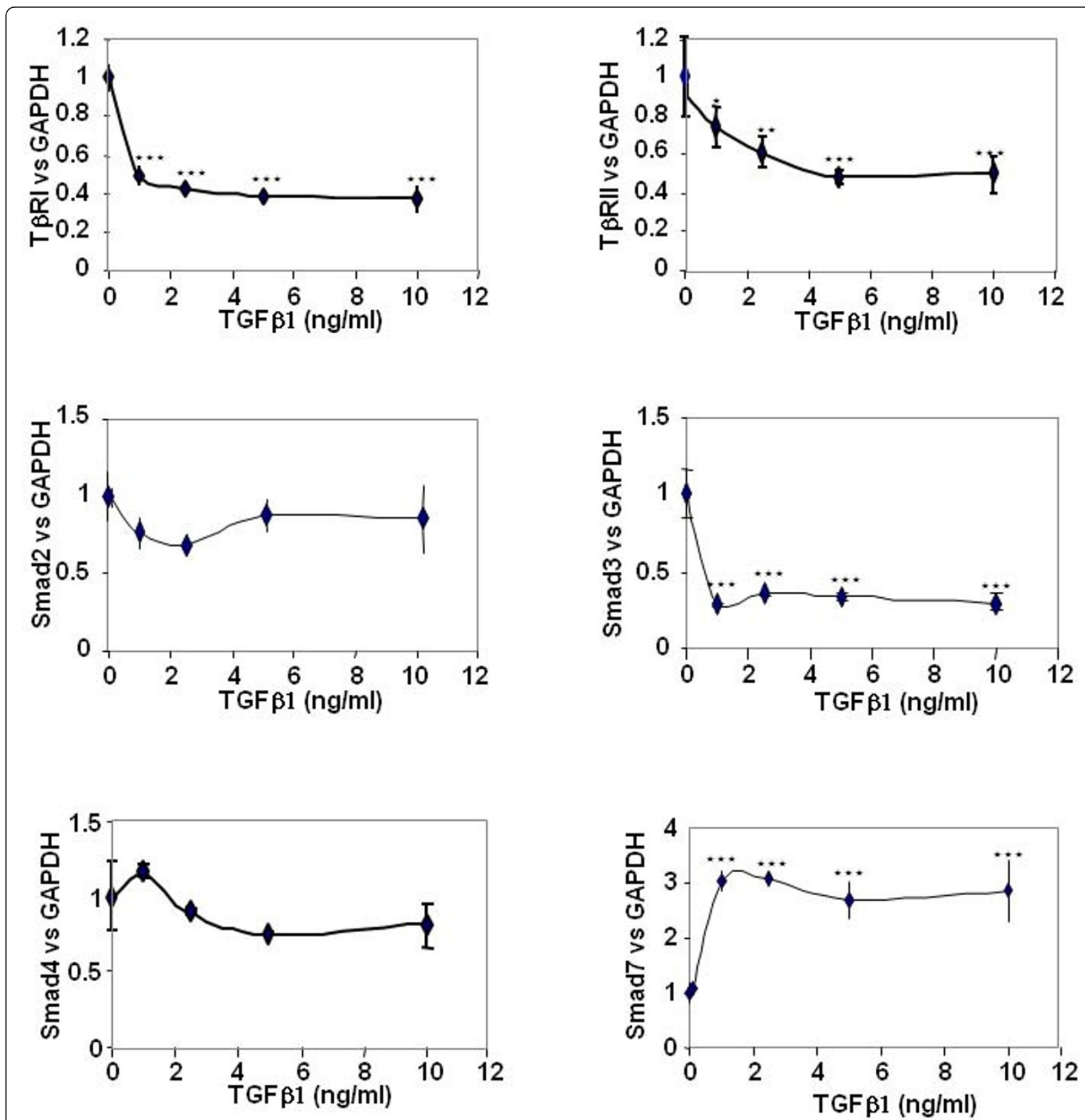

Figure 1 Transforming growth factor beta 1 (TGF $\beta 1$ ) downregulates TGF $\beta$ receptors and Smad3, and upregulates Smad7. Human articular chondrocytes (HAC) were cultured for 5 to 6 days in 10\% FCS-containing DMEM. They were then incubated in DMEM + 2\% FCS with

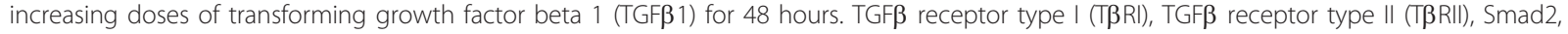
Smad3, Smad4 and Smad7 mRNA were analysed by real-time RT-PCR. The modulation of mRNA expression was expressed relative to the controls (not treated), after normalisation to the GAPDH signal. ${ }^{*}, P<0.05,{ }^{* *}, P<0.01,{ }^{* * *}, P<0.001$

Concerning hypertrophic markers of cartilage, TGF $\beta 1$ induced collagen type $\mathrm{X}$ expression after 24 hours of incubation. We also focused our attention on Sox9, a major transcription factor for the chondrocyte phenotype, and found that TGF $\beta 1$ induced its expression only for 1 hour of incubation.
TGF $\beta 1$ enhances TGF $\beta$ receptor mRNA turnover, but does not modify that of Smads

Modifications of gene expression under TGF $\beta$ treatment could be due to an increased degradation rate and/or a reduced transcription. We therefore asked whether TGF $\beta 1$ affects mRNA decay of T $\beta$ RI, T $\beta$ RII, Smad3 and 

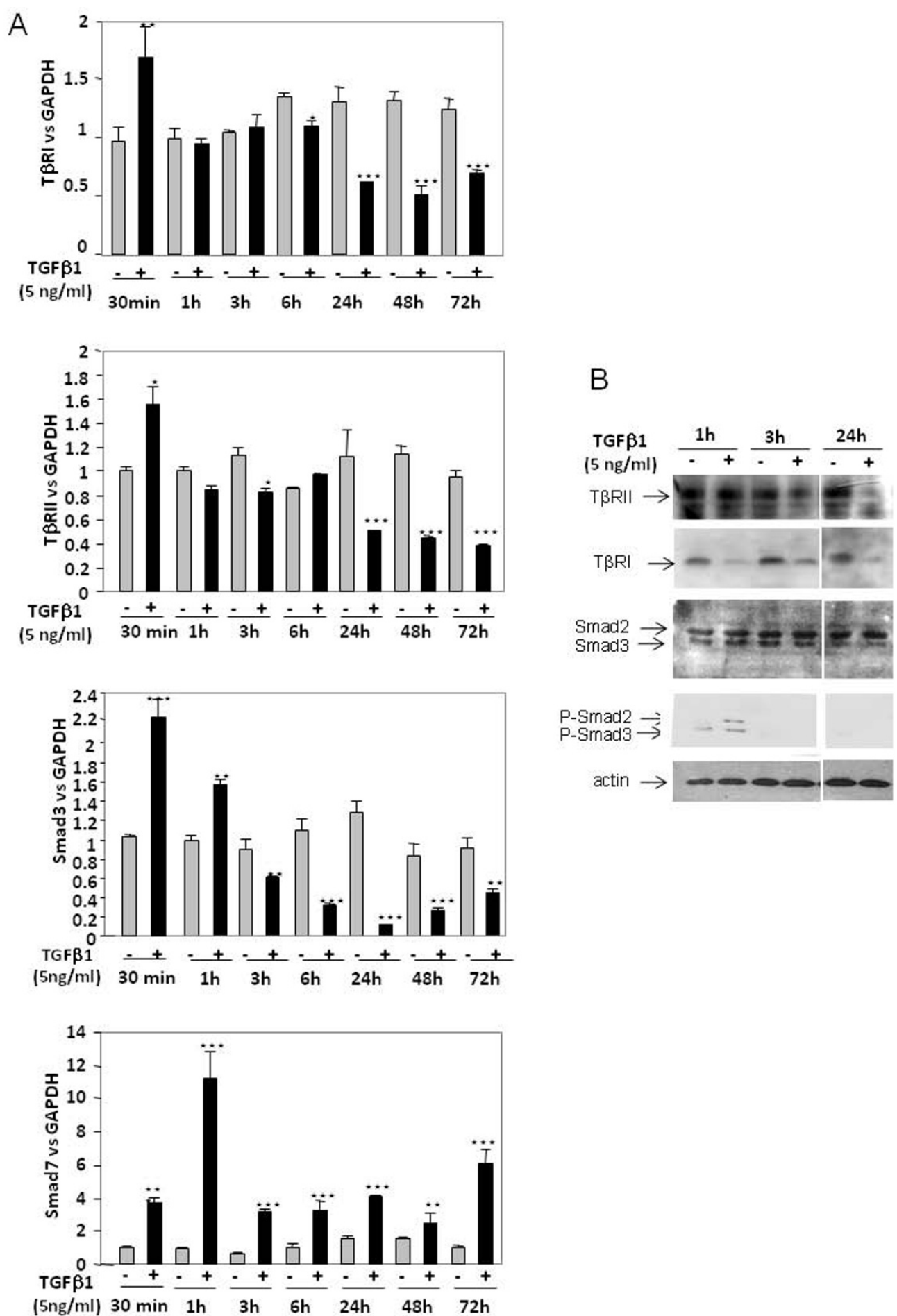

Figure 2 Transforming growth factor beta 1 regulation of receptors and Smad3 expression according to incubation duration (a) Human articular chondrocytes (HAC) were cultured as in Figure 1 and incubated with $5 \mathrm{ng} / \mathrm{ml}$ transforming growth factor beta 1 (TGF $\beta 1$ ) for different times. At the end of incubations, TGF $\beta$ receptor type I (TRRI), TGF $\beta$ receptor type II (T $\beta R I I)$, Smad3 and Smad7 mRNA levels were

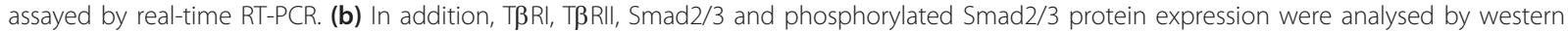
blot analysis. ${ }^{*}, P<0.05,{ }^{* *}, P<0.01,{ }^{* * *}, P<0.001$. 

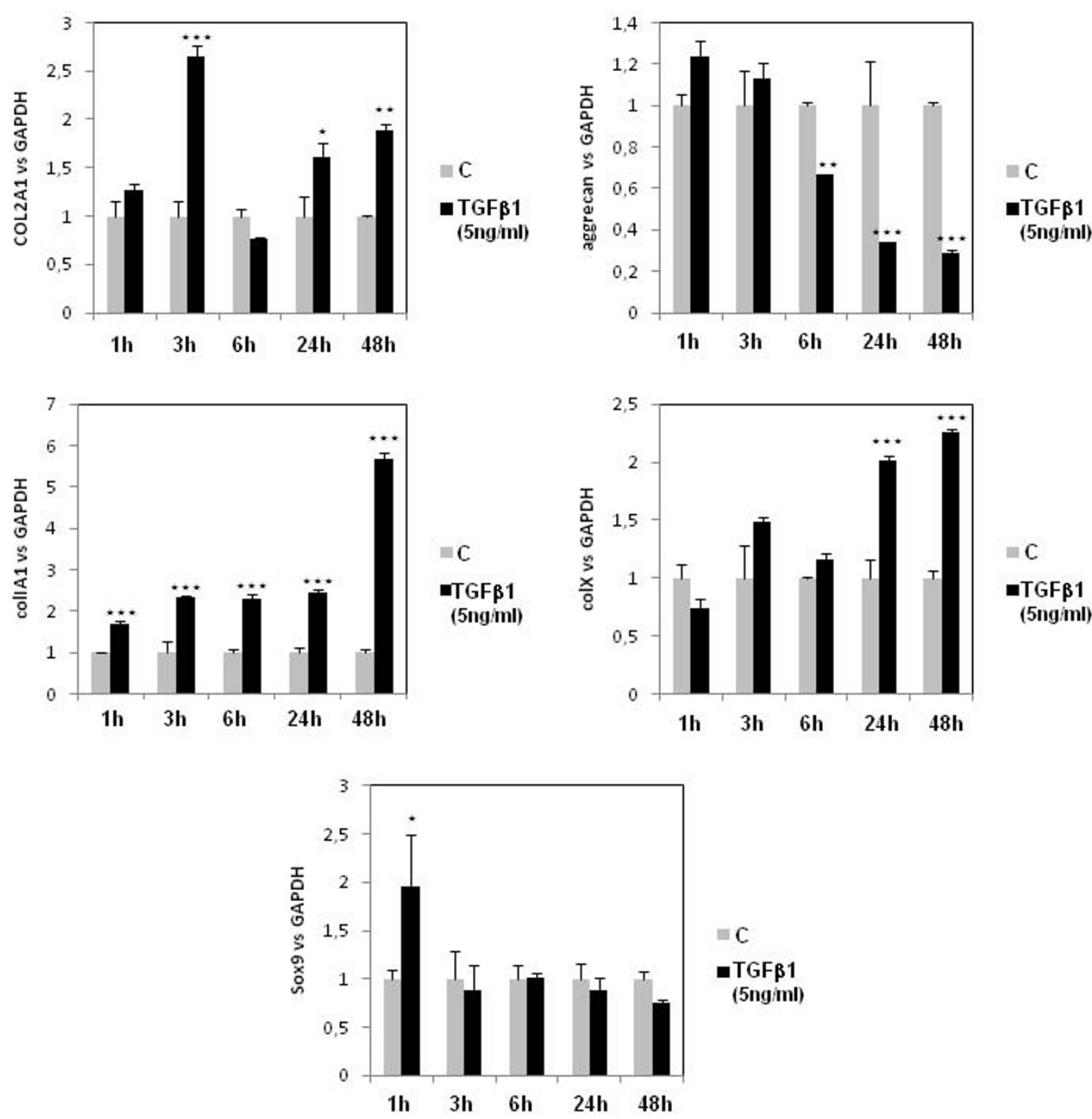

Figure 3 Transforming growth factor beta differential effects on matrix genes and Sox9 according to treatment duration. Human articular chondrocytes (HAC) were cultured and incubated as Figure 2. COL1A1, COL2A1, COL10A1, aggrecan and Sox9 mRNA levels were then determined by RT-PCR. C, control. * $P<0.05,{ }^{*}, P<0.01,{ }^{* *}, P<0.001$.

Smad7. Human articular chondrocytes were incubated with actinomycin $\mathrm{D}$, a transcription inhibitor, in addition to TGF $\beta$ (Figure 4). The half-lives of Smad3 and Smad7 mRNA, which were approximately 3.5 hours and 45 minutes, respectively, were not significantly modified by TGF $\beta$. On the contrary, inhibition of de novo transcription clearly showed that TGF $\beta$ reduced the mRNA half-life of both TGF $\beta$ receptors. Indeed, the T $\beta R I$ half-life is about 20 minutes but was reduced to 10 minutes when chondrocytes were incubated with TGF $\beta$, and the T $\beta$ RII mRNA half-life is 45 minutes for control cells and was reduced by almost $80 \%$ after TGF $\beta$ treatment.

\section{Sp1 mediates TGF $\beta$-induced modulation of TGF $\beta$} receptors

As mentioned above, Sp1 is important for cartilage metabolism. We therefore analysed the effect of TGF $\beta 1$ on Sp1 expression. We showed that TGF $\beta$ strongly reduces $\mathrm{Sp} 1 \mathrm{mRNA}$ levels in a dose-dependent and time-dependent manner (Figure 5).

To further investigate the putative role of Sp1, TGF $\beta$ signalling gene expression was analysed in the presence of mithramycin, an inhibitor of DNA binding of Sp1 family members. Inhibition of Sp1 binding for 24 hours mimics TGF $\beta$-induced repression of receptor expression, whereas it does not affect Smad expression (Figure 6a). 

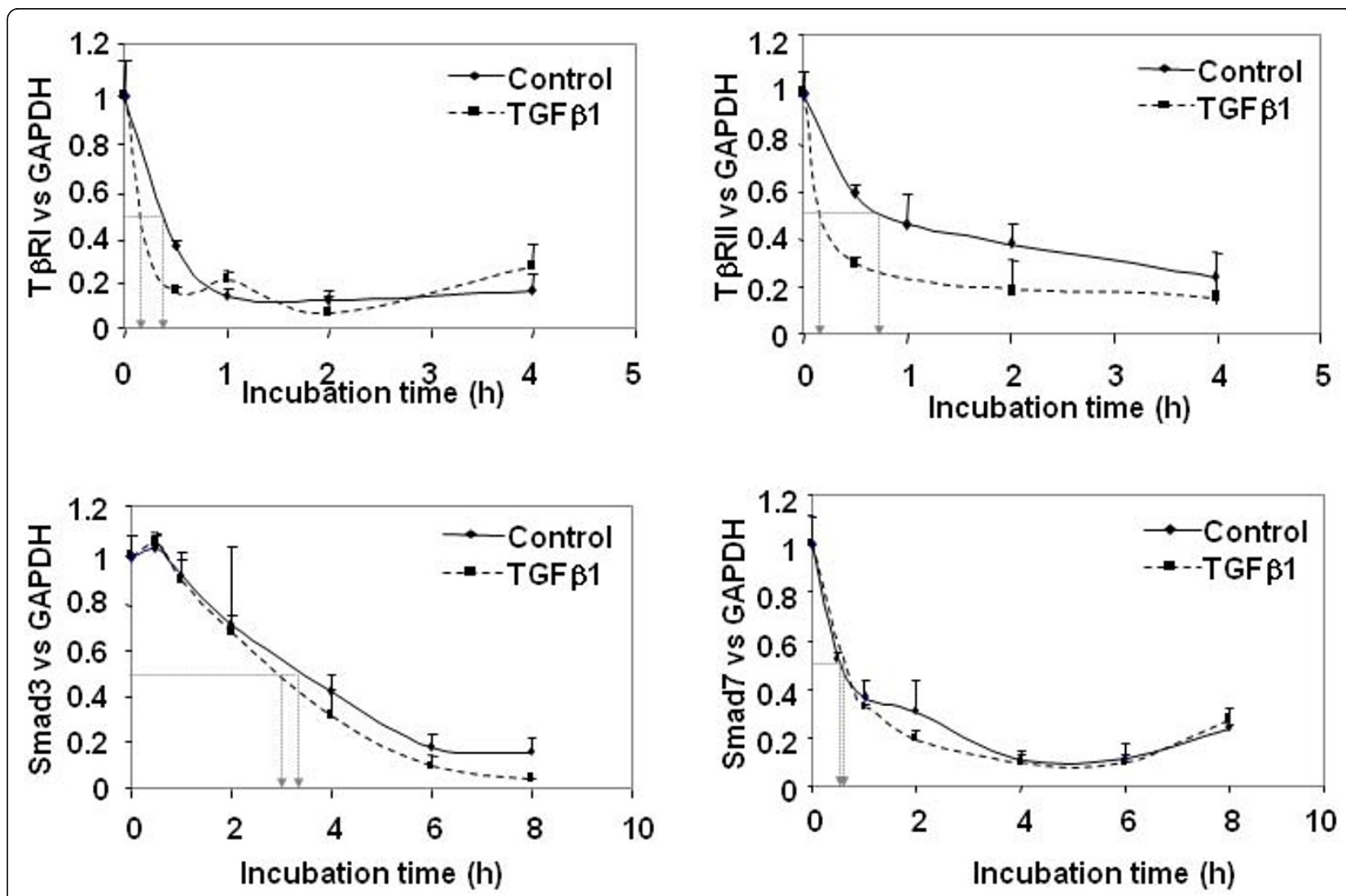

Figure 4 Transforming growth factor beta 1 (TGF $\beta 1$ ) enhances TGF $\beta$ receptors mRNA turnover. Subconfluent human articular chondrocytes (HAC) were incubated with DMEM + 2\% FCS for 24 hours. Thereafter, transforming growth factor beta 1 (TGF $\beta 1$ ) or vehicle were added in the presence of actinomycin D $(10 \mu \mathrm{g} / \mathrm{ml})$. Cells were then harvested at the indicated times for RT-PCR.
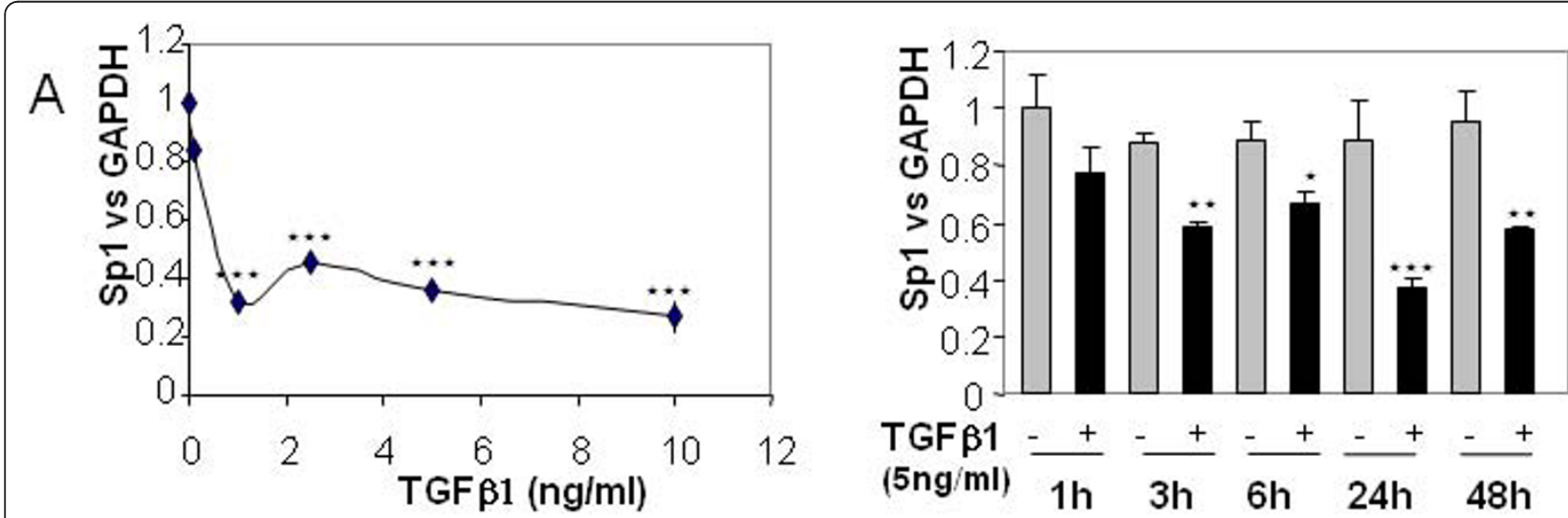

Figure 5 Transforming growth factor beta reduces specific protein 1 mRNA levels dose and time dependently. Human articular chondrocytes (HAC) were cultured for 5 to 6 days in 10\% FCS-containing DMEM. They were then incubated in DMEM + 2\% FCS for 24 hours, before addition of increased concentrations of transforming growth factor beta 1 (TGF $\beta$ 1) or vehicle. mRNA levels of specific protein 1 (Sp1) were analysed by real time RT-PCR. HAC were also treated with $5 \mathrm{ng} / \mathrm{ml}$ TGF $\beta$ and the Sp1 mRNA level was determined. ${ }^{*}, P<0.05,{ }^{* *}, P<0.01$, ***, $P<0.001$. 
To confirm the specific role of Sp1 in these regulations, gain and loss of function experiments were performed. First, silencing of Sp1 by siRNA for 24 hours led to inhibition of both TGF $\beta$ receptor expression but did not modify Smad3 and Smad7 expression (Figure 6b). In contrast, forced expression of $\mathrm{Sp} 1$ for 24 hours did not change T $\beta R I$ and T $\beta$ RII expression but counteracted TGF $\beta$-induced repression on these genes, whereas it did not affect Smad expression either in the presence or in the absence of TGF $\beta$ (Figure 6c). The depletion of Sp1 by siRNA and the overexpression of Sp1 in pEVR2-Sp1 transfected cells were checked by western blot analysis (Figure 7) [13].

\section{Sp1 ectopic expression permits maintaining a similar expression pattern as early response to TGF $\beta$ even after 24 hours of treatment}

Since ectopic expression of Sp1 permits one to counteract the inhibition of T $\beta R I$ and T $\beta$ RII expression induced by long treatment with TGF $\beta$, we hypothesised that it may also affect the expression of downstream genes. We therefore investigated the expression of matrix genes after 24 hours of incubation with TGF $\beta 1$ in cells that had been transfected with $\mathrm{Sp} 1$ expression vector or control vector. Ectopic expression of Sp1 modified cell responses to TGF $\beta$. In Sp1 transfected chondrocytes, 24-hour treatment with TGF $\beta$ induced COL2A1 and Sox9 upregulation but was not able to downregulate aggrecan. Additionally, Sp1 ectopic expression blocked the upregulation of COL10A1 and COL1A1. Interestingly, the gene expression pattern induced by TGF $\beta 1$ at 24 hours under Sp1 ectopic expression (Figure 8) is similar to the early effect of TGF $\beta 1$ at 1 hour in untransfected cells (Figure 3).

\section{Discussion}

To our knowledge, the present study is the first systematic analysis of regulation by TGF $\beta$ on gene expression of its own receptors and Smads, in human articular chondrocytes. Our study shows that TGF $\beta$ exerts a differential effect on the transcription of genes implicated in the canonical Smads pathway. While TGF $\beta$ upregulates its receptors and Smad3 for short incubation (at least at mRNA level), it downregulates them in the long term. In addition, it upregulates Smad7 and does not significantly alter Smad2 and Smad4 expression. This positive and negative feedback loop of the TGF $\beta$ pathway induces differential response of chondrocytes to TGF $\beta$. The mechanisms responsible for modulation of Smads and for TGF $\beta$ receptor expression seem to be different. Indeed, TGF $\beta$ downregulates both receptors, at least by modifying the mRNA stability. This process appears slowly (after 24 hours of treatment). On the contrary, TGF 1 quickly regulates Smad3 and Smad7 mRNA levels by a mechanism independent of mRNA stability.
Our results suggest that following TGF $\beta 1$ administration a rapid activation of TGF $\beta$ signalling occurs, characterised by phosphorylation of $\operatorname{Smad} 2 / 3$ and upregulation of T $\beta$ RI, T $\beta$ RII and Smad3 (at least at mRNA level). Thereafter, a negative feedback loop of the TGF $\beta 1$ signalling pathway occurs with a decline of these receptors and $\mathrm{R}$-Smad expression and a simultaneous rise in the inhibitory Smad7 level. The activation of P-Smad2/3 and upregulation of Smad7 after 30 minutes of TGF $\beta$ treatment are consistent with observations from Jimenez's group obtained with human and bovine chondrocytes [15].

The downregulation of TGF $\beta$ receptors by its own ligand is controversial, and is dependent on cell type as well as on duration of TGF $\beta 1$ incubation. In lung fibroblasts, TGF $\beta 1$ induced an increased type I receptor expression by enhancing the transcription of this gene [16], whereas its expression is not modulated or downregulated in osteoblasts $[17,18]$. Similarly, T $\beta$ RII can be downregulated or upregulated by its own ligand [18-20]. In addition, in osteoblasts TGF $\beta 1$ reduces the amount of specific T $\beta$ RII at the cell surface but does not affect the mRNA steady-state level [21].

We have established that, in human OA chondrocytes, TGF $\beta$ acts, at least in part, by strongly decreasing the mRNA stability of its receptors. This rapid turnover potentially allows the receptor rate to change rapidly in response to its own ligand. We cannot, however, exclude the possibility that TGF $\beta$ downregulates its receptors also at the transcriptional and translational levels.

Concerning Smad effectors, our results are consistent with data obtained in normal skin fibroblasts [22] which demonstrated that TGF $\beta$ treatment causes an upregulation of antagonistic Smad7, and a dramatic decrease in Smad3 mRNA expression. Interestingly, the mRNA level of the closely related Smad2 was not affected by 48 hours of treatment with TGF $\beta 1$. A differential regulation between R-Smads has already been described in lung epithelial and mesangial cells [23,24] and may lead to a variation in the cell response according to the level of TGF $\beta$. Similar to findings obtained in fibroblasts [22] or in mesangial cells [24], we established that the downregulation of Smad3 mRNA expression in TGF $\beta$-treated chondrocytes was not due to decreased transcript stability, suggesting a transcriptional effect of TGF $\beta$. Further experiments, such as nuclear run-on or gene reporter assays, would be required to definitively state this hypothesis.

In contrast to Smad3, Smad7 mRNA expression was rapidly and markedly induced by TGF $\beta$. These findings are agreement with reports describing $\mathrm{Smad} 7$ as an immediate-early gene target of TGF $\beta$ in MV1Lu cells, $\mathrm{HaCaT}$ cells [4] and skin fibroblasts [22]. Increased expression of the inhibitor Smad7 has been associated 

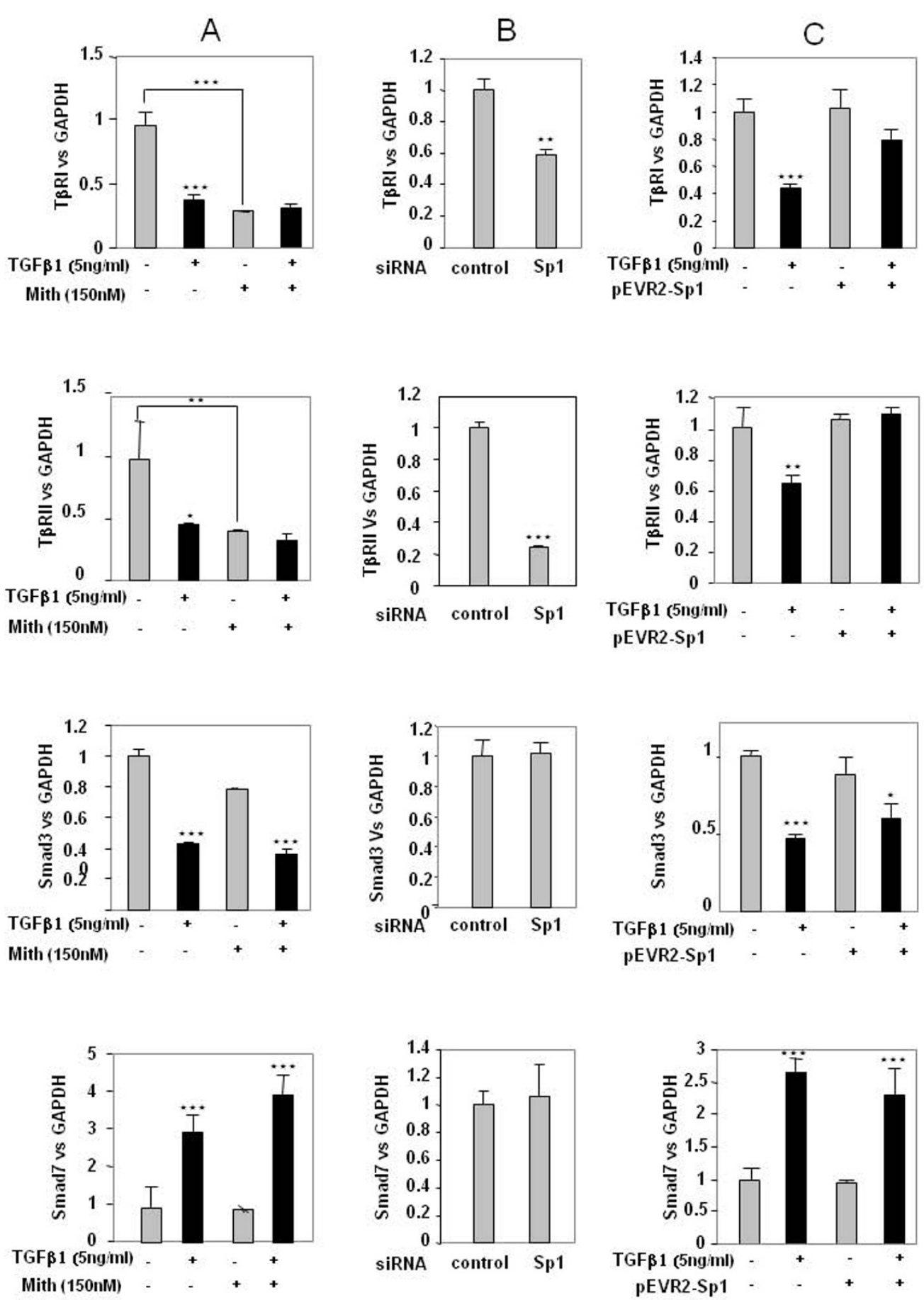

Figure 6 Specific protein 1 mediates transforming growth factor beta (TGF $\beta$ )-induced modulation of TGF $\beta$ receptors. (a) Subconfluent cultures of chondrocytes were treated for 24 hours in the presence or absence of mithramycin (150 nM). TGF $\beta$ receptor type I (T $\beta$ RI), TGF $\beta$ receptor type II (TBRII), Smad3 and Smad7 expression was analysed at the mRNA level by real-time RT-PCR. (b) Human articular chondrocytes (HAC) were also nucleofected with specific protein 1 (Sp1) siRNA oligonucleotides or control sequence. Thereafter, the medium was replaced with DMEM + 10\% FCS for 24 hours. Total RNA was then extracted and real-time RT-PCR analysis was performed. Histograms represent the relative TRRI, TBRII, Smad3 or Smad7 mRNA levels versus GAPDH. (c) HAC were transfected overnight with pEVR2-Sp1 (or with insertless plasmid as controls). Thereafter, media were replaced with DMEM + 2\% FCS for 24 hours in the absence or the presence of transforming growth factor beta 1 (TGFB1) $(5 \mathrm{ng} / \mathrm{ml})$. Therefore, $T \beta R \mathrm{R}, \mathrm{T} \beta \mathrm{Rll}$, Smad3 or Smad7 mRNA levels were analysed and expressed as relative expression versus GAPDH. ${ }^{*}, P<0.05,{ }^{* *}, P<0.01,{ }^{* * *}, P<0.001$. 

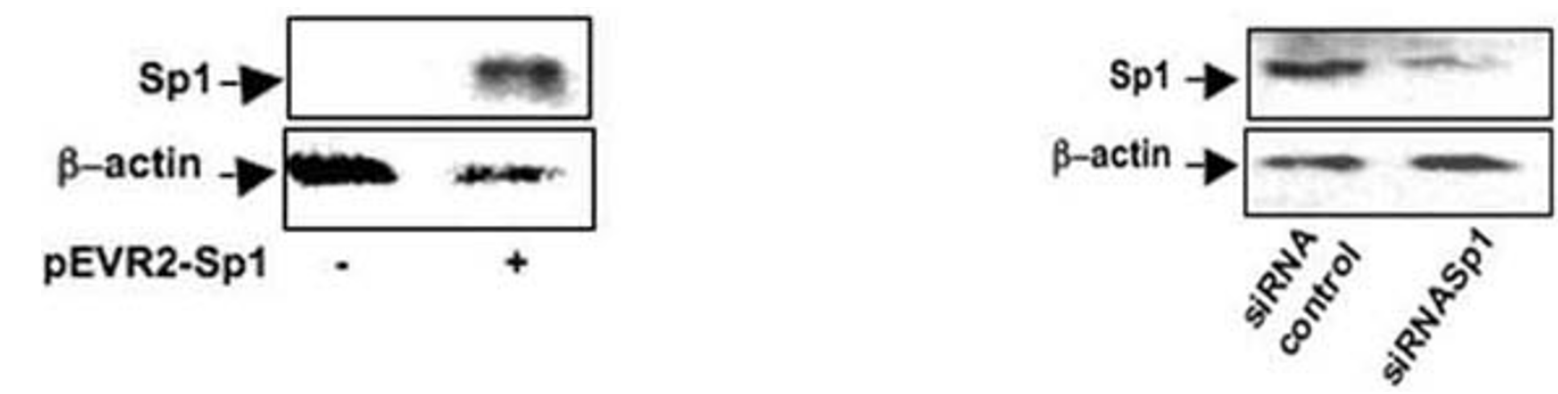

Figure 7 Depletion and overexpression of specific protein 1 by western blot analysis. Human articular chondrocytes (HAC) were treated as in Figure $6 \mathrm{~b}, \mathrm{c}$. At the end of the incubations, protein was extracted and Sp1 protein levels were determined by western blot analysis.

with inhibition of TGF $\beta$ signalling. Smad7 could negatively regulate TGF $\beta$ signalling; on one hand by inhibiting R-Smad activation by T $\beta R I$ or by enhancing T $\beta R I$ degradation in the cytoplasm, and on the other hand by disrupting the formation of the TGF $\beta$-induced functional Smad-DNA complex in the nucleus [25].

These TGF $\beta$-induced modifications on expression of TGF receptors and Smads may participate in the chondrocyte-phenotype changes observed in OA, a pathology associated, at least in the first stage, with an increase in the TGF $\beta$ level [9]. Modifications of Smad3 expression are associated with OA [6,7], and its expression stimulates type II collagen synthesis caused by TGF $\beta 1$ [26]. Moreover, activation of Smad pathways by transfection with a dominant-negative Smad7 retroviral vector or constitutively active T $\beta$ RII abolished retinoic acidinduced inhibition of chondrogenesis, suggesting that TGF $\beta$ receptor/Smad signalling is essential for this process [27]. Furthermore, ectopic expression of T $\beta$ RII restores TGF $\beta$ sensitivity and increases aggrecan and col2 expression, in IL1-treated or passaged chondrocytes, respectively ([14] and unpublished personal data).

Our experiments indicate that TGF $\beta 1$ exerts a differential effect on profiling of gene expression in chondrocytes according to the duration of treatment. A short TGF $\beta 1$ administration (1 hour) induces Sox 9 expression, followed, after 3 hours, by induction of collagen type II expression. This effect was transient, but a second peak of collagen II expression appears after 24 hours of incubation of TGF $\beta 1$. These data suggest that at least two different mechanisms are responsible for cell response to TGF $\beta$. A short TGF $\beta$ administration may activate the Smad2/3 pathway (upregulation of T $\beta$ RI, T $\beta$ RII and Smad3, and phosphorylation of Smad2/3), leading to an increase of Sox9, which, in turn, may induce collagen type II expression. Thereafter, a negative feedback loop occurs, characterised by a reduction of T $\beta R I, T \beta R I I$ and Smad3 expression and simultaneous induction of the inhibitory Smad7. This feedback leads to blockage of Smad2/3-mediated TGF $\beta$ signalling and reduction of
Sox 9 , and furthermore to reduced collagen type II expression.

On the contrary, longer incubation leads an additional response to TGF $\beta$ but with a different pattern of matrix gene expression. This late response is associated with increased atypical collagen expression (COL1A1 and COL10A1) and reduction of aggrecan expression. These data suggest that a noncanonical pathway could be involved in this late response to TGF $\beta$. Several pathways may be implied. In particular, the reduction of T $\beta R I$ expression may change the ratio between $T \beta R I$ and ALK1, another type I TGF $\beta$ receptor recently identified in chondrocytes, favouring TGF $\beta$ signalling via the Smad1/5/8 route and, subsequently, chondrocyte terminal differentiation $[28,29]$.

Finally, in the present report we show that $\mathrm{Sp} 1$ is involved in the regulation of TGF $\beta$ receptors and cell response to TGF $\beta$. TGF $\beta$ acts controversially on Sp1 expression. Previous data obtained in rabbit chondrocytes showed that TGF $\beta$ decreases Sp1 expression and binding activity [30], whereas recent studies indicate that TGF $\beta$ induces Sp1 in skin fibroblasts [31]. Our data show that Sp1 is downregulated in human chondrocytes, suggesting that this negative effect does not depend on the species but is cell-type specific.

The mechanism by which TGF $\beta$ regulates Sp1 expression is still unclear. In particular, the role of Smads in the regulation of $\mathrm{Sp} 1$ promoter activity is not known. Analysis of the Sp1 promoter (region $-2,000$ to +1 ) with Patch_Search [32], however, shows numerous putative binding sites for Smad3 and Smad4 in the 1,000 base pair upstream transcription initiation site of the Sp1 gene. An extensive study will be required to determine whether Smads directly or indirectly regulate $\mathrm{Sp} 1$ expression. Besides, a recent study shows that Smads bind in association with Sp1 to the CC(GG)-rich TGF $\beta 1$ responsive element of the human $\alpha 1$ type I collagen promoter that lacks the classical Smad recognition element, thus enhancing the binding of $\mathrm{Sp} 1$ and in this manner activating the collagen promoter [33]. Numerous studies indicate also 


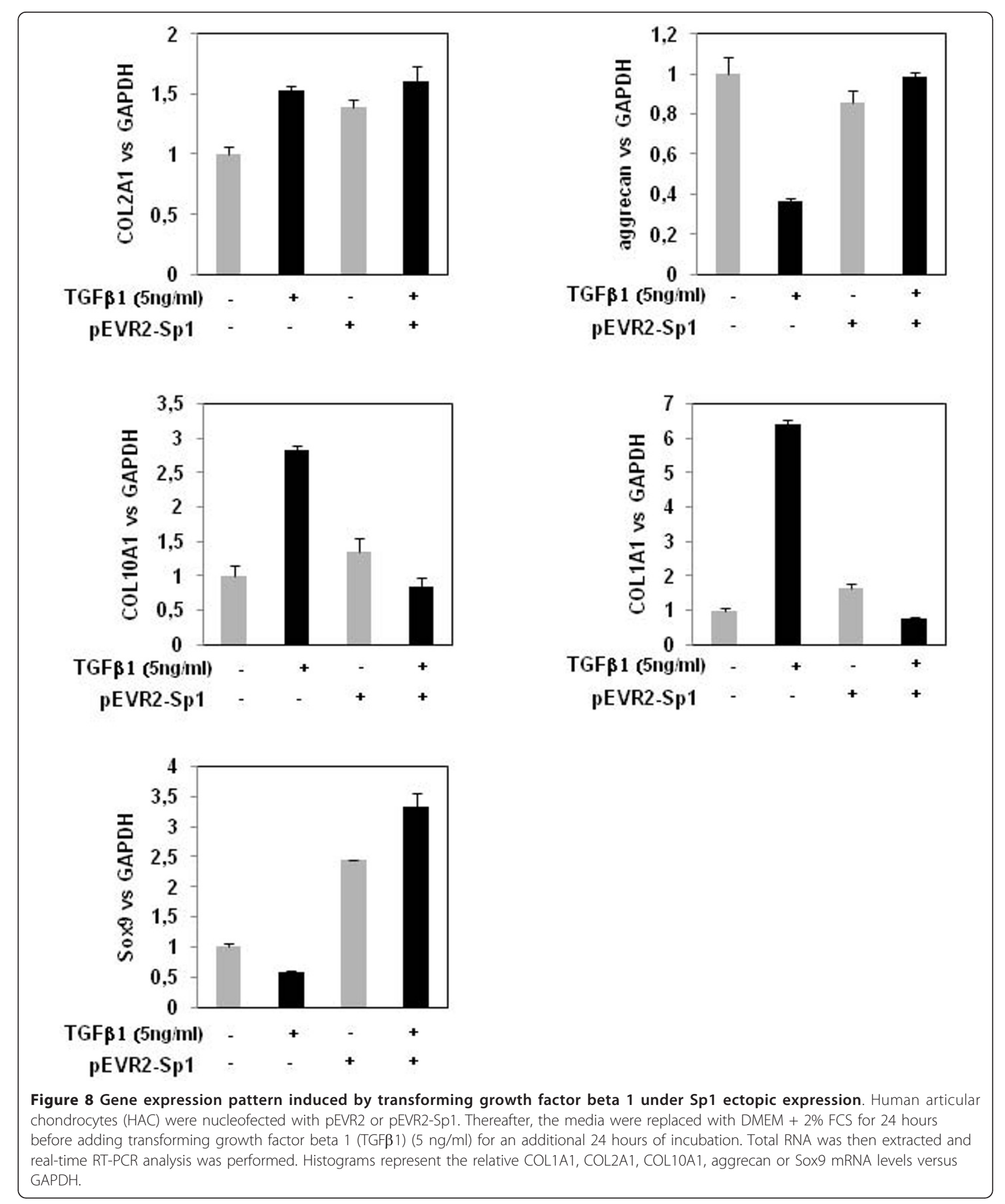


that $\mathrm{Sp} 1$ cooperate with Smads to regulate the expression of TGF $\beta$ target genes [3,31,34,35].

Importantly, restoration by $\mathrm{Sp} 1$ of TGF $\beta$ receptor expression after inhibition by TGF $\beta 1$ strongly suggests that inhibition of Sp1 by TGF $\beta$ is a potential cause of TGF $\beta$-mediated suppression. These results were in agreement with previous reports that demonstrate $\mathrm{Sp} 1$ is a transactivator of both TGF $\beta$ receptors [36,37]. Moreover, a key role of Sp1 in the Smad7 induction by TGF $\beta$ was recently established in pancreatic cancer cells [3]. In our study, however, Sp1 does not regulate Smad7 expression, suggesting that the regulatory mechanism of Smad7 is cell specific.

Interestingly, $\mathrm{Sp} 1$ ectopic expression permits one to maintain, even after 24 hours of treatment, the early cell response to TGF $\beta$ (induction of Sox9, COL2A1) and to counteract the late response (upregulation of COL1A1, COL10A1, repression of aggrecan). These data suggest that targeting Sp1 expression in association to TGF $\beta$ treatment might be an innovative strategy to maintain or induce the chondrocyte phenotype.

\section{Conclusions}

The present study enlightens a mechanism of feedback loop controlling TGF $\beta$ responses in human OA chondrocytes. Contrary to previous studies, which examined one particular gene, we investigated the TGF $\beta$-induced expression of both TGF $\beta$ receptors and Smads, and the molecular mechanism involved. We show that brief administration of TGF $\beta$ induces its signalling with upregulation of TGF $\beta$ receptors and Smad3, which is associated with Sox9 and COL2A1 induction. On the contrary, a long incubation with TGF $\beta$ downregulates its own receptors by decreasing the mRNA stability, reduces the Smad3 expression and upregulates the inhibitor Smad7. In addition, long treatments do not induce Sox 9 expression but upregulate atypical cartilage matrix genes such as COL1A1 and COL10A1. We also provide information about the mechanism involved in this regulation. We showed the implication of the transcriptional factor Sp1 in the repression of both TGF $\beta$ receptors but not in the modulation of Smad3 and Smad7. In addition, we demonstrated the involvement of $\mathrm{Sp} 1$ in both early and late response of these cells to TGF $\beta$. Sp1 ectopic expression permitted one to maintain the early response of OA chondrocytes to TGF $\beta$ at 24 hours of treatment. Together, these data provide an overall view of the feedback loop of the TGF $\beta$ signal in human articular chondrocytes, and highlight an interesting role of $\mathrm{Sp} 1$ in regulating the TGF $\beta$ response.

\section{Abbreviations}

DMEM: Dulbecco's modified Eagle's medium; FCS: foetal calf serum; OA: osteoarthritis; PBS: phosphate-buffered saline; PCR: polymerase chain reaction; R-Smads: receptor-regulated Smads; RT: reverse transcriptase; siRNA: small interfering RNA; Sp1: specific protein 1; T $\beta R I$ : TGF $\beta$ receptor type I; T $\beta R \|$ : TGF $\beta$ receptor type I; TGF $\beta$ : transforming growth factor beta.

\section{Acknowledgements}

The authors thank Dr Suske (Institut fur Molekularbiologie and tumorforschung, Marburg, Germany) for providing pEVR2-Sp1. OC is a recipient of a fellowship from the Conseil Régional de Basse-Normandie.

\section{Author details}

'Université Caen, IFR ICORE 146, Laboratory of Extracellular Matrix and Pathology, Esplanade de la Paix, 14032 Caen cedex, France. ²Department of Orthopaedic Surgery, Saint-Martin Private Clinic, Rue Roquemonts, 14000 Caen, France.

\section{Authors' contributions}

CB conceived and carried out experiments, analysed data and wrote the paper. OC and SL participated in data collection and analysis. PG participated in data interpretation. KB conceived experiments, carried out experiments and analysed data. All authors were involved in writing the paper and had final approval of the submitted and published versions

\section{Competing interests}

The authors declare that they have no competing interests.

Received: 25 June 2010 Revised: 6 January 2011

Accepted: 15 February 2011 Published: 15 February 2011

\section{References}

1. Pujol JP, Chadjichristos C, Legendre F, Baugé C, Beauchef $G$, Andriamanalijaona $R$, Galéra $P$, Boumediene K: Interleukin-1 and transforming growth factor $\beta 1$ as crucial factors in osteoarthritic cartilage metabolism. Connective Tissue Res 2008, 49:293-297.

2. Docagne F, Gabriel C, Lebeurrier N, Lesné S, Hommet Y, Plawinski L, Mackenzie ET, Vivien D: Sp1 and Smad transcription factors co-operate to mediate TGF-beta-dependent activation of amyloid-beta precursor protein gene transcription. Biochem J 2004, 383:393-399.

3. Jungert K, Buck A, Buchholz M, Wagner M, Adler G, Gress TM, Ellenrieder V: Smad-Sp1 complexes mediate TGF $\beta$-induced early transcription of oncogenic Smad7 in pancreatic cancer cells. Carcinogenesis 2006, 27:2392-2401.

4. Nakao A, Afrakhte M, Morén A, Nakayama T, Christian JL, Heuchel R, Itoh S, Kawabata M, Heldin NE, Heldin CH, ten Dijke P: Identification of Smad7, a TGF $\beta$-inducible antagonist of TGF-beta signalling. Nature 1997, 389:631-635.

5. van der Kraan PM, van den Berg WB: Osteoarthritis in the context of ageing and evolution. Loss of chondrocyte differentiation block during ageing. Ageing Res Rev 2008, 7:106-113.

6. Yang X, Chen L, Xu X, Li C, Huang C, Deng CX: TGF-beta/Smad3 signals repress chondrocyte hypertrophic differentiation and are required for maintaining articular cartilage. J Cell Biol 2001, 153:35-46.

7. Yao JY, Wang Y, An J, Mao CM, Hou N, LV YX, Wang YL, Cui F, Huang M, Yang $X$ : Mutation analysis of the Smad3 gene in human osteoarthritis. Eur J Hum Genet 2003, 11:714-717.

8. Serra R, Johnson M, Filvaroff EH, LaBorde J, Sheehan DM, Derynck R, Moses HL: Expression of a truncated, kinase-defective TGF-beta type II receptor in mouse skeletal tissue promotes terminal chondrocyte differentiation and osteoarthritis. J Cell Biol 1997, 139:541-552.

9. Boumediene $K$, Conrozier T, Mathieu P, Richard M, Marcelli C, Vignon E, Pujol JP: Decrease of cartilage transforming growth factor-beta receptor II expression in the rabbit experimental osteoarthritis - potential role in cartilage breakdown. Osteoarthritis Cartilage 1998, 6:146-149.

10. Kaiser M, Haag J, Söder S, Bau B, Aigner T: Bone morphogenetic protein and transforming growth factor beta inhibitory Smads 6 and 7 are expressed in human adult normal and osteoarthritic cartilage in vivo and are differentially regulated in vitro by interleukin-1 $\beta$. Arthritis Rheum 2004, 50:3535-3540.

11. Porée B, Kypriotou M, Chadjichristos C, Beauchef G, Renard E, Legendre F, Melin M, Gueret S, Hartmann DJ, Malléin-Gerin F, Pujol JP, Boumediene K, Galera P: Interleukin-6 (IL-6) and/or soluble IL-6 receptor downregulation of human type II collagen gene expression in articular 
chondrocytes requires a decrease of Sp1.Sp3 ratio and of the binding activity of both factors to the COL2A1 promoter. J Biol Chem 2008, 283:4850-4865.

12. Piera-Velazquez S, Hawkins DF, Whitecavage MK, Colter DC, Stokes DG, Jimenez SA: Regulation of the human SOX9 promoter by Sp1 and CREB. Exp Cell Res 2007, 313:1069-1079.

13. Baugé $C$, Beauchef $G$, Leclercq S, Kim SJ, Pujol JP, Galéra P, Boumédiene K: NFKB mediates IL-1 $\beta$-induced down-regulation of T $\beta R$ III through the modulation of Sp3 expression. J Cell Mol Med 2008, 12:1754-1766.

14. Baugé $C$, Legendre F, Leclercq S, Elissalde JM, Pujol JP, Galéra P, Boumédiene $K$ : Interleukin-1 $\beta$ impairment of transforming growth factor beta1 signaling by down-regulation of transforming growth factor beta receptor type II and up-regulation of Smad7 in human articular chondrocytes. Arthritis Rheum 2007, 56:3020-3032.

15. Roman-Blas JA, Stokes DG, Jimenez SA: Modulation of TGF $\beta$ signaling by proinflammatory cytokines in articular chondrocytes. Osteoarthritis Cartilage 2007, 15:1367-1377.

16. Bloom BB, Humphries DE, Kuang PP, Fine A, Goldstein RH: Structure and expression of the promoter for the R4/ALK5 human type I transforming growth factor-beta receptor: regulation by TGF-beta. Biochim Biophys Acta 1996, 1312:243-248.

17. Kim KK, Ji C, Chang W, Wells RG, Gundberg CM, McCarthy TL, Centrella M: Repetitive exposure to TGF-beta suppresses TGF-beta type I receptor expression by differentiated osteoblasts. Gene 2006, 379:175-184.

18. Centrella M, Ji C, Casinghino S, McCarthy TL: Rapid flux in transforming growth factor-beta receptors on bone cells. J Biol Chem 1996, 271:18616-18622.

19. Wakefield LM, Smith DM, Masui T, Harris CC, Sporn MB: Distribution and modulation of the cellular receptor for transforming growth factor-beta. J Cell Biol 1987, 105:965-975.

20. Massagué J, Like B: Cellular receptors for type beta transforming growth factor. Ligand binding and affinity labeling in human and rodent cell lines. J Biol Chem 1985, 260:2636-2645.

21. Gebken J, Feydt A, Brinckmann J, Notbohm H, Müller PK, Bätge B: Ligandinduced downregulation of receptors for TGF-beta in human osteoblastlike cells from adult donors. J Endocrinol 1999, 161:503-510.

22. Mori Y, Chen SJ, Varga J: Modulation of endogenous Smad expression in normal skin fibroblasts by transforming growth factor-beta. Exp Cell Res 2000, 258:374-383.

23. Yanagisawa K, Osada H, Masuda A, Kondo M, Saito T, Yatabe Y, Takagi K, Takahashi T: Induction of apoptosis by Smad3 and down-regulation of Smad3 expression in response to TGF-beta in human normal lung epithelial cells. Oncogene 1998, 17:1743-1747.

24. Poncelet AC, Schnaper HW, Tan R, Liu Y, Runyan CE: Cell phenotypespecific down-regulation of Smad3 involves decreased gene activation as well as protein degradation. $J$ Biol Chem 2007, 282:15534-15540.

25. Zhang $S$, Fei T, Zhang L, Zhang R, Chen F, Ning Y, Han Y, Feng XH, Meng A, Chen YG: Smad7 antagonizes transforming growth factor beta signaling in the nucleus by interfering with functional Smad-DNA complex formation. Mol Cell Biol 2007, 27:4488-4499.

26. Qiao B, Padilla SR, Benya PD: Transforming growth factor (TGF)-betaactivated kinase 1 mimics and mediates TGF-beta-induced stimulation of type II collagen synthesis in chondrocytes independent of Col2a1 transcription and Smad3 signaling. J Biol Chem 2005, 280:17562-17571.

27. Yu Z, Xing Y: All-trans retinoic acid inhibited chondrogenesis of mouse embryonic palate mesenchymal cells by down-regulation of TGF-beta/ Smad signaling. Biochem Biophys Res Commun 2006, 340:929-934.

28. Blaney Davidson EN, Remst DF, Vitters EL, van Beuningen $H M$, Blom $A B$, Goumans MJ, van den Berg WB, van der Kraan PM: Increase in ALK1/ALK5 ratio as a cause for elevated MMP-13 expression in osteoarthritis in humans and mice. J Immunol 2009, 182:7937-7945.

29. Hellingman CA, Blaney Davidson E, Koevoet W, Vitters EL, van den Berg WB, van Osch G, van der Kraan PM: Smad signaling determines chondrogenic differentiation of bone-marrow derived mesenchymal stem cells: inhibition of Smad 1/5/8P prevents terminal differentiation and calcification. Tissue Eng Part A 2010

30. Chadjichristos C, Ghayor C, Herrouin JF, Ala-Kokko L, Suske G, Pujol JP, Galéra P: Down-regulation of human type II collagen gene expression by transforming growth factor-beta 1 (TGF- $\beta 1$ ) in articular chondrocytes involves SP3/SP1 ratio. J Biol Chem 2002, 277:43903-43917.
31. Ghosh AK, Mori Y, Dowling E, Varga J: Trichostatin A blocks TGF-betainduced collagen gene expression in skin fibroblasts: involvement of Sp1. Biochem Biophys Res Commun 2007, 354:420-426.

32. Patch_Search. [http://www.gene-regulation.com/cgi-bin/pub/programs/ patch/bin/patch.cgi].

33. Sysa P, Potter JJ, Liu X, Mezey E: Transforming growth factor-beta1 upregulation of human alpha(1)(I) collagen is mediated by Sp1 and Smad2 transacting factors. DNA Cell Biol 2009, 28:425-434.

34. Ihn H, Yamane K, Asano Y, Jinnin M, Tamaki K: Constitutively phosphorylated Smad3 interacts with Sp1 and p300 in scleroderma fibroblasts. Rheumatology (Oxford) 2006, 45:157-165.

35. Poncelet AC, Schnaper HW: Sp1 and Smad proteins cooperate to mediate transforming growth factor-beta 1-induced alpha 2(I) collagen expression in human glomerular mesangial cells. J Biol Chem 2001, 276:6983-6992.

36. Periyasamy S, Ammanamanchi S, Tillekeratne MP, Brattain MG: Repression of transforming growth factor-beta receptor type I promoter expression by Sp1 deficiency. Oncogene 2000, 19:4660-4667.

37. Jennings R, Alsarraj M, Wright KL, Muñoz-Antonia T: Regulation of the human transforming growth factor beta type II receptor gene promoter by novel Sp1 sites. Oncogene 2001, 20:6899-6909.

doi:10.1186/ar3247

Cite this article as: Baugé et al:: Modulation of transforming growth factor beta signalling pathway genes by transforming growth factor beta in human osteoarthritic chondrocytes: involvement of $\mathrm{Sp} 1$ in both early and late response cells to transforming growth factor beta. Arthritis Research \& Therapy 2011 13:R23.

\section{Submit your next manuscript to BioMed Central and take full advantage of:}

- Convenient online submission

- Thorough peer review

- No space constraints or color figure charges

- Immediate publication on acceptance

- Inclusion in PubMed, CAS, Scopus and Google Scholar

- Research which is freely available for redistribution

Submit your manuscript at www.biomedcentral.com/submit
Ciomed Central 